\section{DIGITAL COMMONS \\ @ UNIVERSITY OF SOUTH FLORIDA}

\section{ABO: Interactive Journal for Women in the Arts, 1640-1830}

Volume 9

Issue 2 Fall 2019

Article 5

2019

\title{
Review of Margaret Cavendish's Poems and Fancies
}

James Fitzmaurice

Northern Arizona University, j.fitzmaurice49@gmail.com

Follow this and additional works at: https://digitalcommons.usf.edu/abo

Part of the Feminist, Gender, and Sexuality Studies Commons, and the Literature in English, British Isles Commons

\section{Recommended Citation}

Fitzmaurice, James (2019) "Review of Margaret Cavendish's Poems and Fancies," ABO: Interactive Journal for Women in the Arts, 1640-1830: Vol.9: Iss.2, Article 5.

http://doi.org/10.5038/2157-7129.9.2.1223

Available at: https://digitalcommons.usf.edu/abo/vol9/iss2/5

This Digital Humanities is brought to you for free and open access by Digital Commons @ University of South Florida. It has been accepted for inclusion in ABO: Interactive Journal for Women in the Arts, $1640-1830$ by an authorized administrator of Digital Commons @ University of South Florida. For more information, please contact digitalcommons@usf.edu. 


\title{
Review of Margaret Cavendish's Poems and Fancies
}

\begin{abstract}
Liza Blake's free website is sure to become the first stop for anyone beginning work with Poems and Fancies. Most importantly for those who want to explore Cavendish's poetry in depth is that fact that Blake's website provides an easy means of comparison of versions of poems printed in the 1653,1664 , and 1668 editions.
\end{abstract}

\section{Keywords}

Cavendish. Poems and Fancies, editions, conflated texts

Creative Commons License

cc) (1) (9)

This work is licensed under a Creative Commons Attribution-Noncommercial 4.0 License 
Margaret Cavendish's Poems and Fancies. Website with text and introduction by Liza Blake, et al. http://library2.utm.utoronto.ca/poemsandfancies/

Reviewed by James Fitzmaurice

\section{Northern Arizona University}

Northeastern University's Women Writers Online (WWO) and Early English Books Online (EEBO) contain the most heavily used digital editions of Cavendish's writing to be found on the web, but both sites are behind pay walls. There are ways around pay walls, of course, but under the best conditions these ways are a nuisance. Of the good open-access sources, Shawn Moore's Digital Cavendish project is likely the best known and most visited, though there are others including Luminarium. Liza Blake's free website, however, is sure to become the first stop for anyone beginning work with Poems and Fancies, especially undergraduate students and those new to graduate work. Most importantly for senior scholars who want to explore Cavendish's poetry in depth is that fact that Blake's website provides an easy means of comparison of versions of poems printed in the 1653, 1664, and 1668 editions. Revisions, especially between 1653 and 1664, were extensive, and it would be foolhardy for any critic to consult only one text. What Blake has done, then, is to place footnotes where words and phrases have variants, and the reader is able to roll over the numbers with a cursor to immediately see differences. Without this system, a person engaged in criticism would be obliged to find each poem online in all three editions, download, probably print, and compare. Using a rare book library rather than online sources would be even more cumbersome. We may expect, then, that critics of Cavendish's poetry will find Blake's online Poems and Fancies an invaluable aid.

Blake led a team effort organized around a group of undergraduates based at various University of Toronto campuses, especially Mississauga. Her project was too large for a single scholar to undertake, and she wisely chose to train and supervise these students, whom she closely monitored. In bringing students into a major piece of Cavendish scholarship, she is not alone, for Brandie Siegfried at Brigham Young University created a similar undergraduate team who helped to set up an online bibliography of Cavendish's primary and secondary materials. As with Blake's edition, Siegfried's bibliography can be found by way of links from Digital Cavendish and the Cavendish Society websites. Many universities these days provide generous funding for undergraduate research, and the use of students is likely to become more frequent in the future. The experience gained by the undergraduates is invaluable.

The introduction to the online Poems and Fancies focuses on details of the three editions' printing histories and their ownerships and also considers manuscripts. Where printing history is concerned, there is discussion of the nature of textual variants and stop-press correction. Blake has inspected vastly more copies of Poems and Fancies than any other scholar and has provided detailed notes on marginalia as well as other peculiarities of individual copies. Blake and her team have looked at variants to see which might derive from authorial correction and which not, and, controversially, which are the best readings and which not. In the case of "chance" and "change" in "A World Made by Atoms," the temptation is to try to draw some sort of conclusion about Epicurean versus Christian providential views of nature, but she, wisely I think, does not push one word or the other on religious grounds. She finally decides to make a qualified choice for best reading based on correction practices and her choice is "chance." As regards manuscripts, Blake provides an investigation into the tantalizing eighteenth-century suggestion that unprinted poetry by Cavendish survived from the seventeenth in a private collection. If it did, it is lost, at least for the present.

Any editor of Cavendish's verse needs to set the order of poems, a judgment that is not easy, and final decisions come with important benefits and drawbacks. Blake decides to follow the 1653 edition, though with some exceptions. Since Cavendish changed the order of her verse in significant ways for the printing of 1664 and since she for the most part stuck with her changes in 1668 , it might make more sense to follow what was the apparent authorial final view of the arrangement of poems. Blake, however, justifies the 1653 arrangement as producing a "satisfying 
ending" to the first part of the book rather than a "gloomy reflection on how all books are eventually discarded or neglected." I am inclined to see her decision as well within her editorial purview. Modern editors of WH Auden's poetry have had a similar problem: to follow the author's later wishes by printing toned-down versions of the leftist, radical poetry or to print the fierier earlier versions. Again, editorial purview comes into play, and it is mistaken to label one choice or the other as wrong.

Where versions of individual poems are concerned, Blake agrees with Douglas Grant, who prefers the "rough and ragged" meter of the first edition. Grant also says that the "superficial polish" of the later editions hinders the "sincerity and spontaneity of Cavendish's expression." Blake, however, is careful to place some distance between her position and Grant's assertion that the revisions for the later editions were undertaken by someone hired for the job, a "drudge" in the estimation of Sara Mendelson. Although distancing herself from Grant and Mendelson, Blake does not utterly reject the view that someone other than Cavendish worked on regularizing meter in the later editions. Blake's argument, in the end, is that the poems in the 1653 edition are unquestionably unadulterated while the following editions are somewhat suspect.

Blake is a careful and judicious scholar and so is quite willing to look at the benefits to be derived from Brandie Siegfried's choice of the 1668 printing as copy-text for the 2018 Iter Press Poems and Fancies with The Animal Parliament. Siegfried's title reflects a decision to treat the poetry and the prose found in Animal Parliament as two separate works, a view of the volume that Blake does not share. Blake sees value in Siegfried's claim that "by 1664, [Cavendish's] skills as a writer were more polished, an expertise readily visible in the changes she made in the final two editions of the book," but ultimately Blake does not agree. We, as readers of Cavendish, are fortunate to have these two views of the relative merits of Cavendish's revised and unrevised poetry, and it is not necessary to decide between the views, though we are each liable to have inclinations one way or another.

The collection of conflated texts that Blake produces runs against an orthodoxy that severely condemns the practice of working to create "best texts" from multiple editions. She, nevertheless, is quite happy to fly in the face of those textual scholars who deplore what they call "Frankentexts," and I would agree with her that there is genuine value in creating these best texts. It remains to be seen, however, the degree to which the profession will agree or disagree with her readings.

What Blake's edition lacks, especially when compared to Siegfried's, is explanatory notes, notes that point out connections with previous writing on various topics. Siegfried is broadly and deeply familiar with the history of philosophy and scientific thought from Aristotle to Gassendi in ways that few of Cavendish's readers were during her lifetime or are now. Siegfried, for instance, finds verbal echoes of Descartes at the very beginning of The Animal Parliament, when Cavendish writes: "Sits the soul as King in a kernel of the brain." (P. 347, note 1274.) It was often asserted by the likes of Horace Walpole that Cavendish did not read natural history and only wrote it. Such was not the case.

It is to Blake, however, that we are indebted for the free, easy to use, scholarly text of Poems and Fancies, together with excellent textual and general introductions. The choice to highlight in the left-hand margin the "clasps" that bridge larger segments of the volume is a good one. Indeed, the aids to site navigation in that margin work well and the site is generally well marked and easy to use. And, of course, we should be deeply grateful to Blake's extraordinary team of undergraduates. 